\title{
The Impact of Electronic Commerce on Procurement
}

\author{
Benjamin P.-C. Yen \\ School of Business \\ University of Hong Kong \\ Elsie O. S. Ng \\ Department of Industrial Engineering \& Engineering Management \\ Hong Kong University of Science and Technology
}

\begin{abstract}
Internet technology has been increasingly used to enhance the global competitiveness of various business applications through the widespread electronic commerce (EC) functions. Many Internet-based systems have been designed and developed for supply chain management (SCM) in various areas such as computer, garment, and publishing industries, which mainly center on communication infrastructure, coordination between production and distribution, and procurement functions with security mechanisms. However, EC is not a panacea. On many occasions, participants (including buyers, sellers, and enablers) face various risks and overhead during the deployment of a new technology. In this article, we present the impact of EC on procurement processes in supply chains, highlighting the issues of buyers, sellers, and the transaction processes involved. The procurement processes are classified into preprocurement (sourcing), procurement (quotation, negotiation, order placement, and transaction), and postprocurement (delivery). Moreover, a four-phase migration model of procurement onto the Internet is introduced to illustrate the technical, security, and financial requirements in the deployment process of EC. The migration model not only gives a development guideline of procurement functions, but also provides an evaluation framework of e-procurement. An industrial example is used to illustrate the corresponding evolution as a result of EC deployment. The paper concludes with a summary of EC impact and future research directions.
\end{abstract}

electronic commerce, impact study, procurement, SWOT, migration process, supply chain management

\section{INTRODUCTION}

The traditional market of electronic commerce (EC) was founded in the 1990s along with the rapid growth of the Internet. By 1991, EC was mainly supported by

Correspondence and requests for reprints should be sent to Benjamin P.-C. Yen, School of Business, University of Hong Kong, Pokfulam Road, Hong Kong. E-mail: benyen@business.hku.hk 
five basic facilities: electronic mail (e-mail), enhanced fax, electronic data interchange (EDI), transaction processing, and groupware; by 1995 EC began to mature with the emphasis of security with a variety of secure transaction processing services [1]. In the 21st century, EC has become a very hot topic in both the research and business areas, and, among the many definitions of EC, we can simply summarize EC as the buying and selling activities of information, products, and services via computer networks [2]. It has been an increasing trend for companies to migrate their businesses onto the Internet. What are the reasons for the individual companies to invest such a vast amount of time and money into this new business strategy? Is it because they want to sell on the Internet in order to increase sales, or are they just following it as a competitive business norm to establish their visibility in the electronic market? With whatever reasons they bear, companies are gradually moving their procurement functions such as sourcing, negotiating with suppliers, and coordination with research and development (R\&D) onto the Internet. In other words, they are trading in an electronic fashion. Thus, the term electronic procurement (e-procurement) was recently invented to describe these activities that are taking place in the electronic market. E-procurement results in greater control and flexibility along with cost savings in the procurement operations and provides suppliers with the ability to become more proactive in the way they do business.

The degree to which different companies wanted to get involved with EC varies, therefore in this article we made the assumption that any company that migrates its procurement onto the Internet does not necessarily adopt EC completely. Our objective is to classify the impact of EC on procurement by migrating businesses onto the Internet with the justification of our ongoing Hong Kong Textile Apparel Industry Global Application (HKTAIGA) project. Such migration of a procurement process from the traditional trade to EC may reengineer the business processes, such as a direct information and material flow from one entity to another in the EC-based supply chain, for example, from manufacturer to retailers, whereas the intermediates, for example, distributors, are disintermediated from the traditional trade as shown in Figure 1.

The purpose of this study is to investigate any drawbacks as well as benefits within the procurement of EC in order to improve the current situation, and to minimize any uncertainties incurred during the migration. Moving procurement onto the Internet is not yet mature, although many researchers already paid attention to this area some years ago. When this idea becomes mature, the whole procurement process may be automated electronically, or some may be minimized, merged together, or even transformed into other processes.

This article is organized as follows: Section 2 reviews the literature of EC, procurement, e-procurement, and impact study. Section 3 describes the framework of EC impact on procurement with the four-phase of migration of business process and the classification of impact factors in the procurement of supply chain. A case study is described in Section 4, and finally the conclusion highlights the implications of the research result for general EC applications and future research directions. 


\section{Traditional Supply Chain}

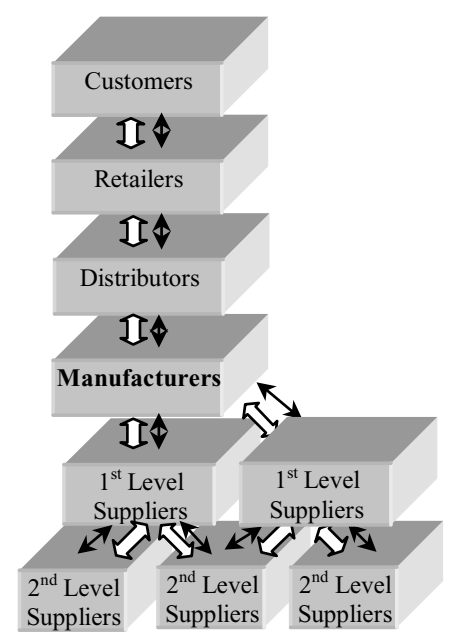

EC-based Supply Chain

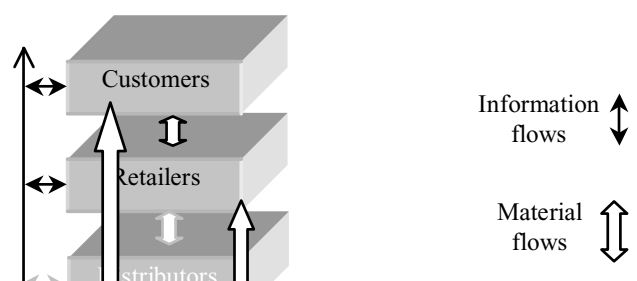

Figure 1. The information/material flow processes of two types of B2B commerce.

\section{LITERATURE REVIEW}

Before companies launch EC by migrating their businesses onto the Internet, careful planning of the migration is necessary. With KLM, a Dutch cargo company, Christiaanse and Zimmerman [3] discussed the requirements needed and challenges faced when potential companies adopted use of electronic channels as well as how KLM applies electronic channels to reduce costs and improve responsiveness among several different parties. "The Swatch Group" migrated their supply chain onto the Internet, although their transaction functions can be facilitated with the automated information flow within the supply chain and efficient communications between buyers and sellers [4]. Srinivasan et al. [5] pointed out that by migrating the supply chain onto the Internet, both the key players and organizational activities would be adjusted, accompanied by both challenges and opportunities. Such challenges and opportunities include careful planning of the ways that people integrate changes, and the benefits that the Internet can bring to the business such as reduction in overall costs, respectively. Loebbecke et al. [6] illustrated how the largest academic bookseller, Co-op Bookshop, launched EC and the difficulties that they faced when competing globally. They suggested that a company should study the existing customers and markets before it deploys EC on the Internet. They also provided guidelines about the resources required for setting up and maintaining a Web site and ways to integrate the existing business into the Internet. Matsuda [7] investigated the barriers for the adoption of the Japanese electronic produce market system (EMS) by examining the current status of the produce market, and suggested a way to implement EMS under the current status around such market. Sadeh et al. [8] illustrated how the supply chain could launch EC with their proposed system, MASCOT (multi-agent supply chain coordination tool), which results in the enhancement of real-time planning and scheduling functions throughout the 
whole supply chain in order to achieve a more effective and efficient way to coordinate production and transportation.

Procurement supports a delivery-relationship between buyers and sellers [9]. Being a broader scope than "purchasing," procurement involves strategic activities such as sourcing, negotiating with suppliers, and coordination with R\&D [10]. Alt el al. [4] divided procurement into two phases; contracting and settlement. The contracting phase consists of sourcing and available to promise (ATP), and the settlement phase consists of transaction and delivery. Sourcing is the searching of requirement information of goods/services on the Internet, and ATP is the information flow with a supply chain, that is, the availability of goods and the shipping arrangement. Such information flow usually acts as an information exchange within the functions of quotation and negotiation. Transaction is the payment of goods/services, and delivery is the moving of goods/services from seller to buyer.

E-procurement is more than putting purchasing decisions online, its functions also include linking suppliers and buyers into the purchasing network and rethinking of business processes such as transactions [11]. With efficient information, such product information is structured by e-catalogs with which e-procurement can form a good basis in order to attract more buyers to the shopping site [12]. Shell Services International launched its e-procurement service as a cost-cutting driver in July 2000. Its e-catalogues contain a broad list of suppliers ranging from huge contract partners to small chemical producers with which Shell has prenegotiated discounts and service contracts. When a purchasing order is received, it will be automatically forwarded to the appropriate suppliers [13]. Avery [14] illustrated how e-procurement could reduce costs and cycle time by having a better relationship between buyers and sellers with a vertical supply chain. The introduction of an e-procurement system in Texas Instruments has reduced the number of transactions in which purchasing was involved and replaced the internally based catalog system, while saving a significant amount of cost [15]. The Texas-based Burlington Northern Santa Fe Railway, Fort Worth (BNSF) planned to apply e-procurement for strategic sourcing and SCM as they believed that collaboration with their suppliers could be facilitated in order to achieve full contract discount pricing [16]. The printing company, Lexmark, also took advantage of the strengths of e-procurement to enhance the relationship with both their customers and suppliers in order to deliver materials in their supply chain [17].

E-procurement could also result in negative cost impact incurred by manufacturers such as carrying excess inventory, poor transaction turnaround times, and uncertainties in supplier inventory and production schedules [18]. On the other hand, depending on the characteristics of product or service, e-procurement might not be suitable for some high-specification goods or services where tight relationships between buyers and suppliers are essentially required [11]. As a start, it is always critical for managers to ensure that their workers are motivated to use the e-procurement system when introducing it as well as the existing paper-based system [19].

In the literature, many researchers have studied the impact of EC on procurement. Croom [20] carried out a Delphi study to explore the impact of Web-based procurement systems on MRO purchasing and classified them as operational and strategic benefits. The operational benefits include the ability to reduce overall procurement costs and the improved audit of each transaction within the process. The strategic benefits refer to greater influence and control over procurement 
expenditure. Gebauer et al. [21] studied the impact of the Internet on the procurement, in particular the transaction process of a purchasing department focusing on the impact of buyer-supplier relationships over the Internet. They introduced a scale of six measurements for the requirements of a purchasing function in the Internet, ranging from cost, time, satisfaction, quality, stock, and value. Rhodes and Carter [22] discussed the impact of EC on changing the product distribution in the textile apparel sector in the following aspects: globalization of production and retailing, evolution in retailing, evolving patterns of competition, pressures on small and medium-sized enterprises (SMEs), customization, and production of "batch of one." IBM and Micron achieved benefits by migrating their procurement onto the Internet [23]. IBM could reduce its total procurement cost and time by $\$ 240$ million in 1999 . Micron has gained a reduction in paper, cost, and inventory with its purchase order (PO) process, and moreover, its whole procurement was sped up. On the other hand, Philips [24] and Hill [25] investigated the impact of information technology (IT) on the supply chain of computer and apparel manufacturer's respectively. Philips [24] proposed that by shortening the supply chain (SSC), "favorable impact" can be achieved such as reduction in procurement time using EDI, better planning by collaborating effectively with suppliers and customers, increase in the flexibility of response to change, reduction in both time and cost by delivering goods directly from suppliers to customers, and enhanced communications with customers by electronic media. Similarly, Hill [25] recognized the impact as transport to change in the respects of information exchange in order to provide better decisions, better relationship between manufacturers and suppliers, better collaboration between retailers and manufacturers, and exchanging information in a paperless environment.

\section{THE FRAMEWORK OF THE EC IMPACT ON PROCUREMENT}

EC focuses on the process improvement of interorganizational transactions unlike SCM which concerns the material and information flow coordination. An analysis of EC and SCM reveals a complementary relationship with some overlappingEC concentrates on shaping information and contracting activities, and SCM primarily focuses on planning process and the organization of various flows [4]. From the two findings of Alt el al. [4] and Koppius [9], as described in Section 2, we have derived a classification of business processes of procurement: preprocurement, procurement, and postprocurement. Preprocurement mainly involves sourcing, procurement consists of quotation, negotiation, order placement and transaction, and delivery is the process of postprocurement.

Sourcing is the searching for required information of goods/services on the Internet with e-catalogs. A database system is required to store the product records of the e-catalogs and text- or image-based search engines are sometimes applied to facilitate the search results. A quotation is a request directed to the supplier of cost according to the product specification of buyers, and negotiation allows buyers to inquire about anything concerning with the deal. Both quotation and negotiation are supported by electronic communication infrastructures such as e-mails and message/discussion boards. Order placement allows buyers to specify the product 
requirements, payment method, and delivery details in the electronic modifiable order form and such information will be stored in the database system. For transactions, there are traditional and electronic payments.

In general, there are three categories of traditional payments: cash, documents, and credit cards. Cash consists of notes and coins that are issued by some large authorized banks and is bulky to carry but retains user anonymity. Documents include personal checks and money orders written by an accepted authority such as banks and post offices. Credit cards range from Visa/Master Card to debit cards. They do not maintain user anonymity but identify both the payer and receiver, thus the transactions are traceable. An item could be paid before delivery using documents, or credit cards, or paid on delivery with cash (also called credit on delivery, COD), document, or credit cards depending on the terms and policy of sellers and agreement between buyers and sellers. With credit cards, a small charge such as an annual fee is paid to the issuing authority of cards. These are indeed convenient to use but bear many security problems such as forged signatures on stolen cards.

There are various forms of electronic payment in which some are widely accepted and used, but others are still in revolutionary stage. They include financial electronic data interchange (F-EDI), "home banking," and electronic cash (e-cash) [26]. F-EDI transmits payment transactions and associated remittance advice data from a payer's to a receiver's bank account. Like the Australian F-EDI system, it can avoid many of the costs, errors, and delays inherent in documentary-based payment mechanisms such as personal checks [27]. Home banking allows a payer to conduct a payment using an electronic payment device at home, which is very convenient. An example of home banking is CyberCash, which is a credit type of system where payment is guaranteed before an item is shipped to avoid credit card transaction fraud [28]. E-cash transforms cash into electronic form in which the payer connects to the Internet and pays for the item through the Internet such as Mondex, which can carry "value" up to five different currencies that can be transferred to a seller via a telephone line or the Internet [29].

Shipment is responsible for the logistic body in which collaboration between suppliers and the logistic body is required, for example, the exchange/flow of information is essential to ensure that the item is delivered to the customer. Such information includes time, location, and transportation mode of delivery. The information of demand can be used to forecast future demand and gain better inventory control. With EC, once the customer has submitted an order online with his or her preferred delivery date, a notification with confirmed date is returned back to the customer [30]. The delivery information is sent to the logistic body for delivery.

From what other researchers have done, we have summarized a twodimensional table (as shown in Table 1) with a planning or brainstorming purpose, illustrating the impact of buyer and seller with respect to the business process of procurement, with the classification of impact as strengths, weaknesses, opportunities, and threats (SWOT). Strengths and weaknesses are for measuring the internal performance of the procurement prcess, for example, efficiency and effectiveness, and external opportunities and threats are identified in the electronic environment in which the procurement is operating [31]. For instance, 
Table 1

The Categorization of EC Impact on the Procurement Functions

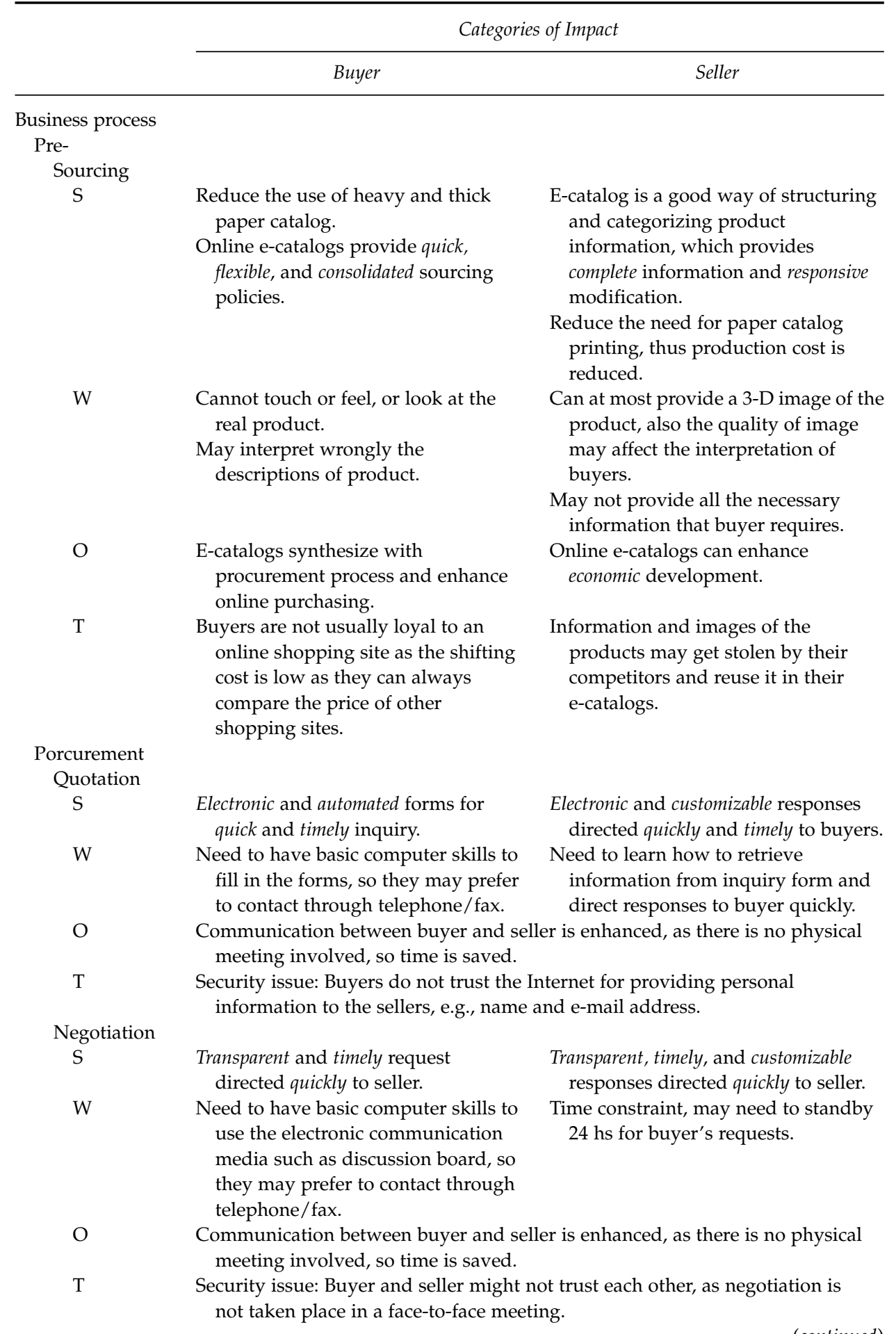


Table 1 (Continued)

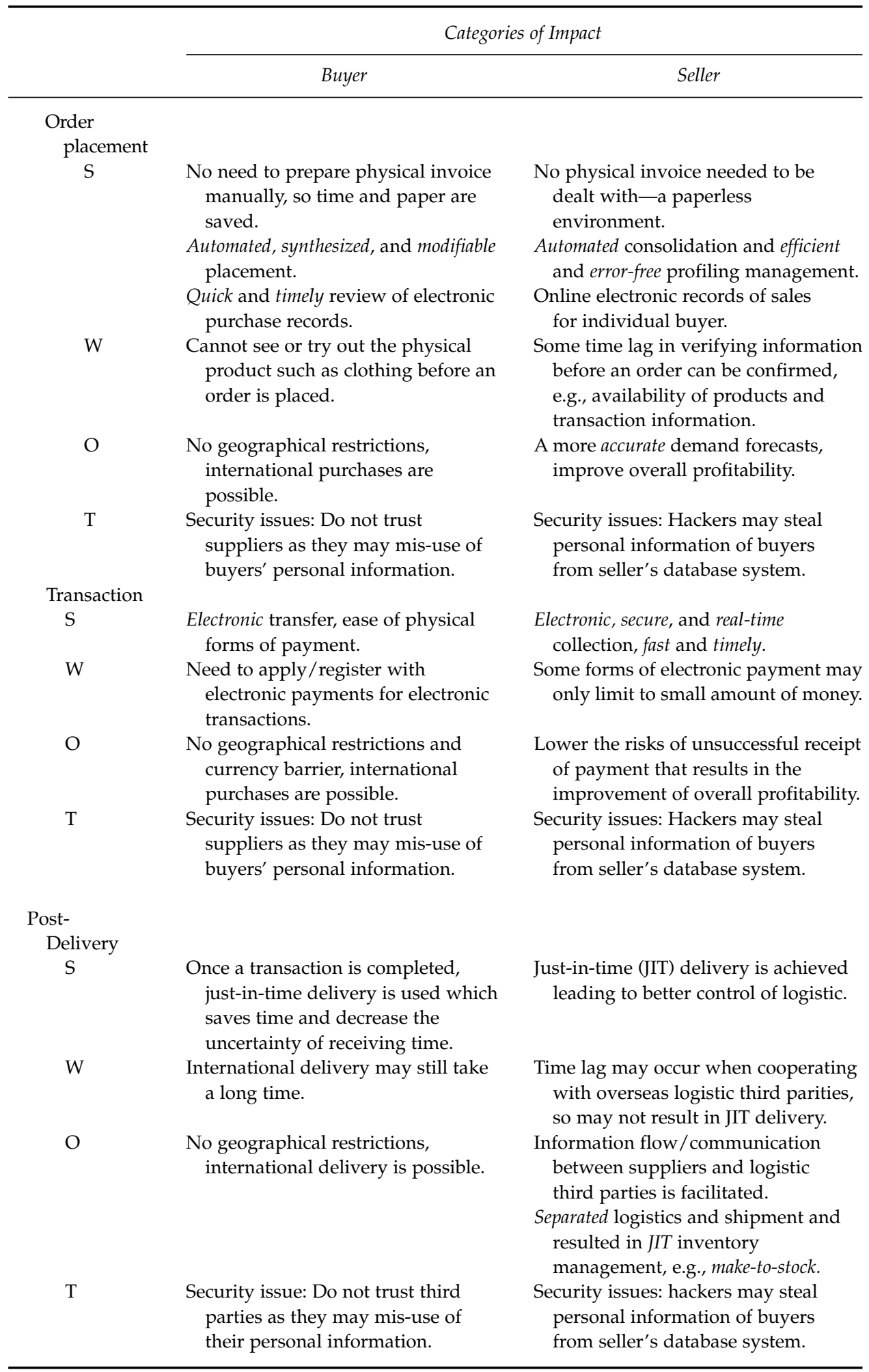


during negotiation, buyers can benefit from a quick and timely enquiry in which communication between a buyer and a seller is enhanced, saving time with electronic and automated inquiry forms. However, both the buyers and sellers need to have basic computer skills to use the electronic inquiry forms, and buyers may not trust the Internet to provide personal information to the sellers. Therefore, in order to minimize such weaknesses and threats, as well as to maximize the benefits that can be gained from the migration, careful planning is essential. We have proposed Table 2, a four-phase migration model with technical, security, and financial requirements, as a plan for the migration of the procurement process onto the Internet.

\subsection{The Four-Phase Migration Model of the Procurement Process onto the Internet}

The first phase of migration is the digitization of data with database systems arranged in a local area network (LAN) to manage the information storage and retrieval within the company. In order to maintain such a system, security and financial issues such as login and password control and firewalls to protect the LAN, and costs for computer hardware/software and staff training should be treated as important as technical requirements. The next phase is the setup of communication infrastructures with other companies where information is transferred or exchanged within the interorganizational connections through e-mails and EDI. Costs for Internet access and building of EDI and e-mail systems, and a more sophisticated firewall to protect such systems are required. The third phase is the implementation of an EC front-end system for the procurement business processes where information processing can be facilitated with Web sites and search engines. Costs for staff training for the implementation and maintenance of the EC front-end system as well as technical and EC consultations, and a firewall to protect such systems are required. The last phase is the integration of a vertical portal where the EC front-end system is coordinated with third parties, such as transaction and logistic bodies. For security reasons, data are encrypted for information transaction as well as protecting such a complicated system with firewalls. There are also costs for maintaining such a system and transaction charges paid to the third parties, such as banks and logistic bodies. In addition, an authentication access model should be carefully implemented with each phase as different access rights are given to different functional staff or users to avoid the misuse of information.

As we have made the assumption in the introduction that not every company would adopt EC fully while migrating their procurement functions onto the Internet, companies may not necessarily need to implement all four phases or start from the first phase, depending on the existing technical requirements of the companies. One should be aware that the degree of expertise, intangible costs, complexity of information, security, and uncertainties increase from phase one to phase four, therefore careful planning is necessary with the migration of a procurement process on to the Internet in order to achieve a positive impact as described in Table 3. Weaknesses and threats are neglected from this table as we 
Table 2

The Four-Phase Migration Model of Procurement Process onto the Internet

\begin{tabular}{|c|c|c|c|c|}
\hline Phase & Features & Technical & Requirements Security & Financial \\
\hline $\begin{array}{l}\text { 1st phase } \\
\text { Data digitization }\end{array}$ & $\begin{array}{l}\text { Information storage and retrieval } \\
\text {-Convert paper-based file } \\
\text { information storage into } \\
\text { digitized and automated } \\
\text { information system. } \\
\text {-Information content focused with } \\
\text { LAN within the company. }\end{array}$ & $\begin{array}{l}\text { - Basic computer hardware and software, } \\
\text { e.g., word processing-automation } \\
\text { - Database system-information storage } \\
\text { and retrieval } \\
\text { - LAN within the company } \\
\text { - Training given to staffs for basic } \\
\text { computer skills }\end{array}$ & $\begin{array}{l}\text { - Basic authentication } \\
\text { rights-login and } \\
\text { password control } \\
\text { - Firewalls to protect LAN }\end{array}$ & $\begin{array}{l}\text { - Cost for computer } \\
\text { hardware and software } \\
\text { - Training course fees }\end{array}$ \\
\hline $\begin{array}{l}\text { 2nd phase } \\
\text { Communication } \\
\text { infrastructures }\end{array}$ & $\begin{array}{l}\text { Information transfer/exchange } \\
\text { Interorganizational connections / } \\
\text { inter-communications: connect } \\
\text { and enhance communications } \\
\text { with other companies through } \\
\text { e-mails and EDI }\end{array}$ & $\begin{array}{l}\text { - Software and hardware for Internet } \\
\text { access and EDI } \\
\text { - Network for e-mail system } \\
\text { - Further training given to staffs if } \\
\text { necessary }\end{array}$ & $\begin{array}{l}\text { - A more sophisticated } \\
\text { firewall to protect EDI } \\
\text { and e-mail system as } \\
\text { well as the LAN }\end{array}$ & $\begin{array}{l}\text { - Start up and monthly } \\
\text { subscription costs for } \\
\text { - Internet access } \\
\text { - Costs for building the } \\
\text { - EDI and e-mail system }\end{array}$ \\
\hline $\begin{array}{l}\text { 3rd phase } \\
\text { EC front-end } \\
\text { system }\end{array}$ & $\begin{array}{l}\text { Information processing } \\
\text { Implement the procurement } \\
\text { business processes such as } \\
\text { building Websites and search } \\
\text { engines }\end{array}$ & $\begin{array}{l}\text { - Software and hardware for } \\
\text { implementation of EC front-end system } \\
\text { - Technical staffs with EC knowledge for } \\
\text { implementation of EC front-end system }\end{array}$ & $\begin{array}{l}\text { - Membership schemes for } \\
\text { readers-login and } \\
\text { password control } \\
\text { - Firewall to protect EC } \\
\text { front-end system }\end{array}$ & $\begin{array}{l}\text { - Costs for hiring both } \\
\text { technical and EC } \\
\text { consultants }\end{array}$ \\
\hline $\begin{array}{l}\text { 4th phase } \\
\text { Integration of } \\
\text { vertical portal }\end{array}$ & $\begin{array}{l}\text { Information processing (with } \\
\text { third party co-ordinations) } \\
\text { Form portal: integrate chain } \\
\text { coordinations with third party } \\
\text { for business functions, such as } \\
\text { credit card company for } \\
\text { transactions and logistic } \\
\text { department for delivery }\end{array}$ & $\begin{array}{l}\text { - Infrastructure for the coordinations } \\
\text { with third party } \\
\text { - Technical staffs with EC knowledge for } \\
\text { implementation of further } \\
\text { - EC front-end applications }\end{array}$ & $\begin{array}{l}\text { - Data encryption for } \\
\text { transaction information } \\
\text { as well as firewall } \\
\text { - A more complicated } \\
\text { authentication model, } \\
\text { i.e., only staffs who deal } \\
\text { with transactions as well } \\
\text { as the } \\
\text { - Third party has the } \\
\text { authentication to access } \\
\text { credit cards information }\end{array}$ & $\begin{array}{l}\text { - Setup and maintenance } \\
\text { costs for such } \\
\text { infrastructure } \\
\text { - Transaction charge paid } \\
\text { to third party }\end{array}$ \\
\hline
\end{tabular}


assume that they will be minimized with the four-phase migration-planning model.

\subsection{The Categorization of Impact of EC in the Procurement Process}

The impact of EC in the procurement process is classified into buyer and seller, which is further divided into individual and interorganizational categories as shown in Table 3. Individual and interorganization classifications represent the internal efficiency and external impact, respectively. With sourcing, buyers can search for quick and complete information of materials from suppliers' online electronic catalogs while purchasing is enhanced. During quotation and negotiation, sending inquiries with the electronic and automated inquiry forms to suppliers can save time, and in return suppliers would direct them with quick and customizable responses, while communication between buyers and sellers is facilitated. With automated, synthesized, and modifiable order placement, cost and time are saved while purchase records can be viewed in a quick and timely fashion. Suppliers can benefit from efficient and error-free profiling management and more accurate demand forecasts in order to improve overall profitability. Again, communications between buyers and sellers can be enhanced while time is saved. Electronic transactions can be done without the need of physical forms of payment that are not restricted to geographical and currency barriers. Suppliers can benefit from secure real-time collection of payment while the risk of unsuccessful receipt of payment is lowered resulting in a profitability improvement. With delivery, uncertainty of receiving time is reduced by separated logistics and shipment, while information flow or communication between suppliers and logistic third parties is facilitated.

\section{CASE STUDY: ELECTRONIC COMMERCE IN A TEXTILE/GARMENT INDUSTRY}

Since the case study, HKTAIGA is a textile-based project in Hong Kong, therefore, in this section we will describe the textile industry in Hong Kong and give details of TAIGA as well as the impact summary of EC on the procurement of the textile industry.

\subsection{The Textile and Apparel Industry and Its Supply Chain in Hong Kong}

The textile and apparel industry stands out as one of the most globalized industries in the world today. This differs from buyer-driven supply chains led by multinational companies. The apparel industry is a supply-driven commodity chain led by a combination of retailers, contractors, subcontractors, merchandisers, buyers, and suppliers; each plays an important role in a network of supply chains that span from fibers to yarn, to fabrics, to accessories, to garments, to 
Table 3

The Categorization of Impact of EC in the Procurement Function

\begin{tabular}{|c|c|c|}
\hline & \multicolumn{2}{|c|}{ Categories of Impact } \\
\hline & Buyer & Seller \\
\hline \multicolumn{3}{|c|}{ Business process } \\
\hline \multicolumn{3}{|c|}{ Pre- } \\
\hline \multicolumn{3}{|c|}{ Sourcing } \\
\hline \multirow[t]{2}{*}{ ID } & $\begin{array}{l}\text { Online electronic catalogs for quick, } \\
\text { flexible and consolidated sourcing } \\
\text { policies }\end{array}$ & \multirow[t]{2}{*}{$\begin{array}{l}\text { Online electronic catalogs with complete } \\
\text { information and responsive } \\
\text { modification }\end{array}$} \\
\hline & $\begin{array}{l}\text { Reduce the use of paper-based } \\
\text { catalogs }\end{array}$ & \\
\hline IO & $\begin{array}{l}\text { E-catalogs synthesize with } \\
\text { procurement processes, purchasing } \\
\text { is enhanced }\end{array}$ & $\begin{array}{l}\text { Online e-catalogs can enhance economic } \\
\text { development }\end{array}$ \\
\hline \multicolumn{3}{|c|}{ Procurement } \\
\hline \multicolumn{3}{|c|}{ Quotation } \\
\hline ID & $\begin{array}{l}\text { Electronic and automated forms for } \\
\text { quick and timely inquiry }\end{array}$ & $\begin{array}{l}\text { Electronic and customizable responses } \\
\text { directed quickly and timely to buyers }\end{array}$ \\
\hline IO & \multicolumn{2}{|c|}{$\begin{array}{l}\text { Communication between buyer and seller is enhanced, as there is no physical } \\
\text { meeting involved, so time is saved }\end{array}$} \\
\hline \multicolumn{3}{|c|}{ Negotiation } \\
\hline ID & $\begin{array}{l}\text { Transparent and timely request } \\
\text { directed quickly to seller }\end{array}$ & $\begin{array}{l}\text { Transparent, timely, and customizable } \\
\text { responses directed quickly to seller }\end{array}$ \\
\hline IO & \multicolumn{2}{|c|}{$\begin{array}{l}\text { Communication between buyer and seller is enhanced, as there is no physical } \\
\text { meeting involved, so time is saved }\end{array}$} \\
\hline \multicolumn{3}{|c|}{ 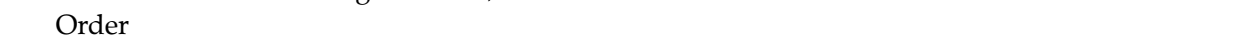 } \\
\hline \multirow[t]{3}{*}{ ID } & $\begin{array}{l}\text { No need to prepare physical invoice } \\
\text { manually, so time and paper are } \\
\text { saved }\end{array}$ & $\begin{array}{l}\text { No physical invoice needed to be dealt } \\
\text { with-a paperless environment }\end{array}$ \\
\hline & $\begin{array}{l}\text { Automated, synthesized, and modifiable } \\
\text { placement }\end{array}$ & $\begin{array}{l}\text { Automated consolidation and efficient } \\
\text { and error-free profiling management }\end{array}$ \\
\hline & $\begin{array}{l}\text { Quick and timely review of electronic } \\
\text { purchase records }\end{array}$ & $\begin{array}{l}\text { Online electronic records of sales for } \\
\text { individual buyer }\end{array}$ \\
\hline $\mathrm{IO}$ & $\begin{array}{l}\text { No geographical restrictions, } \\
\text { international purchases are } \\
\text { possible }\end{array}$ & $\begin{array}{l}\text { A more accurate demand forecasts, } \\
\text { improving overall profitability }\end{array}$ \\
\hline \multicolumn{3}{|c|}{ Transaction } \\
\hline ID & $\begin{array}{l}\text { Electronic transfer, ease of physical } \\
\text { forms of payment }\end{array}$ & $\begin{array}{l}\text { Electronic, secure, and real-time collection, } \\
\text { fast and timely }\end{array}$ \\
\hline $\mathrm{IO}$ & $\begin{array}{l}\text { No geographical restrictions and } \\
\text { currency barrier, international } \\
\text { purchases are possible }\end{array}$ & $\begin{array}{l}\text { Lower the risks of unsuccessful receipt } \\
\text { of payment that results in the } \\
\text { improvement of overall profitability }\end{array}$ \\
\hline \multicolumn{2}{|c|}{ Delivery } & \\
\hline ID & $\begin{array}{l}\text { Once transaction is completed, } \\
\text { just-in-time delivery is used which } \\
\text { saves time and decrease the } \\
\text { uncertainty of receiving time }\end{array}$ & $\begin{array}{l}\text { Just-in-time delivery is achieved leading } \\
\text { to better control of logistic }\end{array}$ \\
\hline
\end{tabular}


Table 3 (Continued)

\begin{tabular}{ccc}
\hline & \multicolumn{2}{c}{ Categories of Impact } \\
\cline { 2 - 4 } IO & $\begin{array}{c}\text { No geographical restrictions, } \\
\text { international delivery is possible }\end{array}$ & $\begin{array}{c}\text { Information flow/communication } \\
\text { between suppliers land logistic third } \\
\text { parties is facilitated }\end{array}$ \\
& $\begin{array}{c}\text { Separated logistics and shipment and } \\
\text { resulted in just-in-time inventory } \\
\text { management, e.g., make-to-stock }\end{array}$ \\
\hline
\end{tabular}

Note. $\mathrm{ID}=$ individual, $\mathrm{IO}=$ Interorganization.

trading, and to marketing. Geographically, they span multicontinents and cut across regional and national boundaries.

The supply chain of the textile industry involves product design and development, material sourcing and product manufacturing, product distribution, and retailing of products. The product design stage should involve customers in order to define and fulfill their requirements. The product and raw material sources development process has 45 days of lead time with $60 \%$ of the prototypes. From manufacturing to delivery to distributors, the lead time is 30 days with a total of 8 inventory turns annually. The delivery lead time from the distributors to the retailers is $24 \mathrm{~h}$ with $90 \%$ of order fulfillment. Therefore, the whole supply chain process may take at least 76 days [32]. Figure 2 illustrates the parties and business processes involved in a textile supply chain.

The 1995 report of the Hong Kong Government Industry Department [32] states that the raw material suppliers faced the problems of limited variety and availability of materials; and with the shrinking profit margin and advent of modern computing communication networks, it is imperative that Hong Kong's textile and apparel industry should seriously consider establishing a cost-effective IT infrastructure to maintain their competitive edge.

\subsection{HKTAIGA Trading Online}

HKTAIGA is an ongoing project funded by the Hong Kong Government since 1994. The government saw the need to provide an efficient communication channel for the SMEs, including suppliers and their buyers in the textile and apparel industry in Hong Kong, as most of them could not afford to invest in Internet-based technology and could not take the risk of experiencing errors. There are four phases in the development of HKTAIGA as summarized in Table 4: (a) catalog browser system in client/server architecture, (b) Web-based communication infrastructure, (c) electronic front-end system for SMEs, and (d) horizontal and vertical portals. The first stage started with the name Hong Kong Clothing Information Network System (HKCAINS), in which the information system was only used within the company. As it proceeded into the second phase, it changed its name to HKTAIGA, while extending the communication 


\begin{tabular}{|l|l}
\hline Academia & Universities/Technical Institutes/Training Institutes (local/overseas) \\
\hline Accessory & Basic and fashion garment trims \\
\hline Apparel Buyers & Retailers/Buying Houses/Agents (local/overseas) \\
\hline Associations & Textile/Garment/General/Industry/Trade/Special (local/overseas) \\
\hline Chemicals & Dye stuff/Chemicals/Printing Inks suppliers \\
\hline Financial Institutions & Banks/Insurance/Factors etc. \\
\hline Garment Exporters & Traders/Manufacturers \\
\hline Garment Manufacturers & HK/Regional/International/Global \\
\hline Government & Trade \& Industry/Education/Customs \\
\hline Logistic Providers & Sea \& Air forwarders etc. \\
\hline Machinery & Textile/Garments/Technology Enablers \\
\hline Textile & Spinners/Weavers/Knitters/Dyers/Printers/Yarn/Greige suppliers \\
\hline Textile Equipment & Machinery Suppliers/Technology suppliers \\
\hline
\end{tabular}

(a) Organization in a textile supply chain

\begin{tabular}{|l|l|c|l}
\hline $\mathbf{1}$ & Product idea submitted and discussed & $\mathbf{2 0}$ & Pick up shipment \\
\hline $\mathbf{2}$ & Research materials supplier initiated & $\mathbf{2 1}$ & Return loaded containers \\
\hline $\mathbf{3}$ & Exchange product idea with potential manufacturers & $\mathbf{2 2}$ & Submit bay plan \\
\hline $\mathbf{4}$ & Collect material samples & $\mathbf{2 3}$ & Apply Export License \\
\hline $\mathbf{5}$ & Submit product prototype & $\mathbf{2 4}$ & Issue Export License \\
\hline $\mathbf{6}$ & Apply export quota & $\mathbf{2 5}$ & Submit relevant documents \\
\hline $\mathbf{7}$ & Visit to review material and prototype & $\mathbf{2 6}$ & Issue Bill of Lading \\
\hline $\mathbf{8}$ & Search revised prototype & $\mathbf{2 7}$ & Submit Export Manifest \\
\hline $\mathbf{9}$ & Submit quota & $\mathbf{2 8}$ & Submit Import Manifest \\
\hline $\mathbf{1 0}$ & Final approval prototype and material & $\mathbf{2 9}$ & Informing shipment status \\
\hline $\mathbf{1 1}$ & Order placement material & $\mathbf{3 0}$ & Shipment arrival notice \\
\hline $\mathbf{1 2}$ & Order placement manufacturing & $\mathbf{3 1}$ & Submitting Import License \\
\hline $\mathbf{1 3}$ & Opening L/C for material and manufacturing & $\mathbf{3 2}$ & Instructing freight forwarders for shipment pick- \\
\hline $\mathbf{1 4}$ & Submit L/C & $\mathbf{3 3}$ & up and delivery \\
\hline $\mathbf{1 5}$ & Fabric delivery & $\mathbf{3 3}$ & Customs clearance and shipment pick-up \\
\hline $\mathbf{1 6}$ & Basic shipment instructions & $\mathbf{3 4}$ & Shipment delivery \\
\hline $\mathbf{1 7}$ & Shipment booking and shipment instructions & $\mathbf{3 5}$ & DC arrival notice \\
\hline $\mathbf{1 8}$ & Instruct release of empty containers to shipper & $\mathbf{3 6}$ & Store delivery \\
\hline $\mathbf{1 9}$ & Pick up empty containers & $\mathbf{3 7}$ & Store arrival notice \\
\hline
\end{tabular}

(b) Typical business processes in a textile supply chain

Figure 2. Typical parties and business processes in a textile supply chain.

channel to a global level and later migrating it onto the Internet in the third phase. The last phase extended the system into a portal in 2001. The last phase has been extending the system into a portal in 2001 to cover the entire apparel and textile business community including the whole merchandising process to provide supports on operational management and transactional activities, as well as linkages to supporting industries, like logistics providers, bankers etc. It is built on a secured e-commerce platform covering four major areas: Infrastructural Portal, Encyclopedic Portal, Business Operation Portal, and Sourcing \& Transactional Portal.

The architecture of HKTAIGA is a combination of databases, client/server modules, and Web-based systems for sourcing in textile and garment applications as shown in Figure 3 [33]. The EC front-end system supported by Web browsers (such as Netscape) is shown in Figure 4, and the back-end system acts as a combination of a database server and a Web server (such as the Internet information server). The client application provides various procurement functions and offers tools to catalog products, for example, templates are provided to companies for the generation of their own Web site and online catalogs. The search engine supports both image and text search functions that consist of a 
Table 4

The Four-Phase Migration Process onto the Internet of HKTAIGA

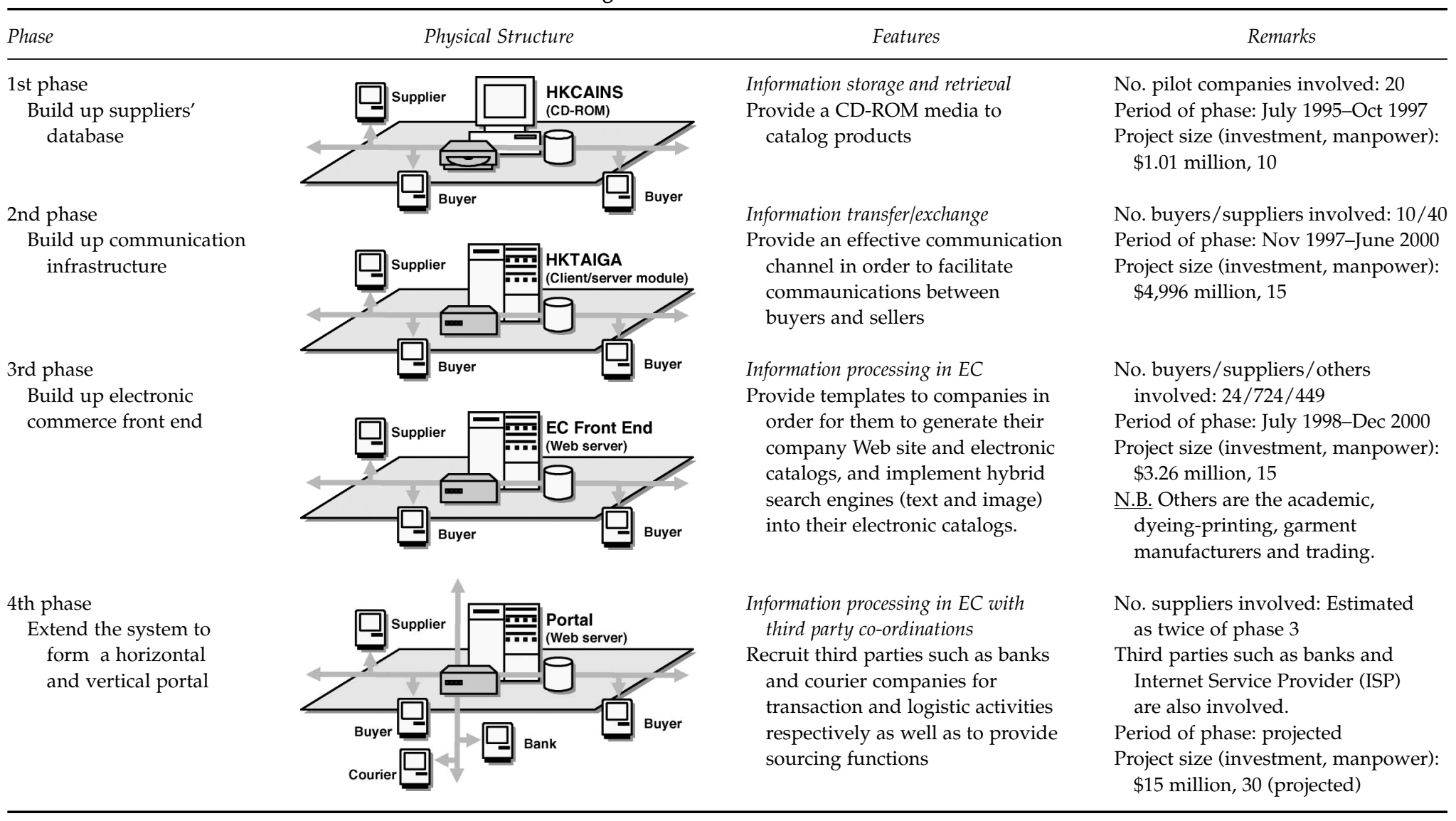




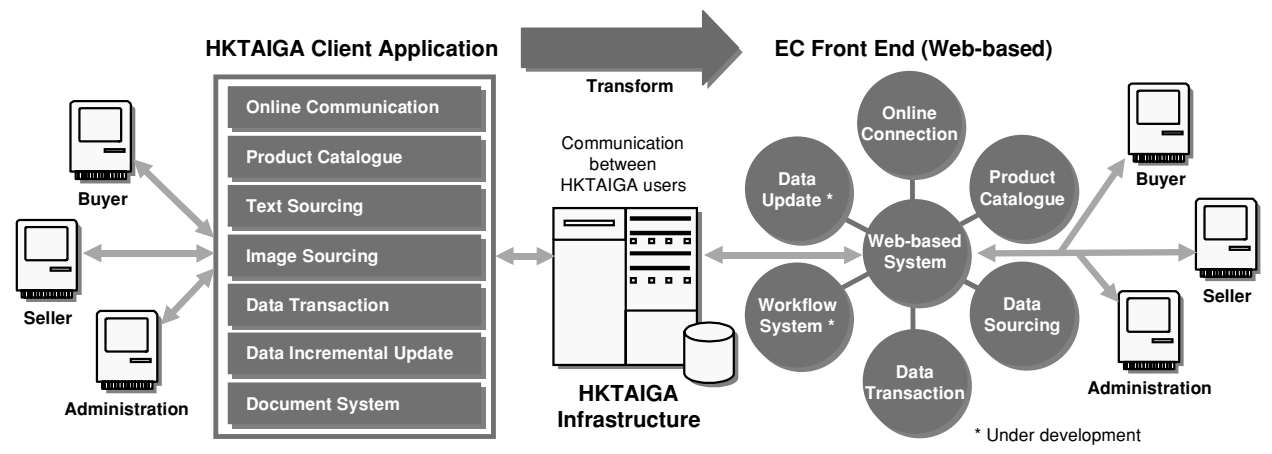

Figure 3. The architecture of HKTAIGA for client/server and Web-based application.

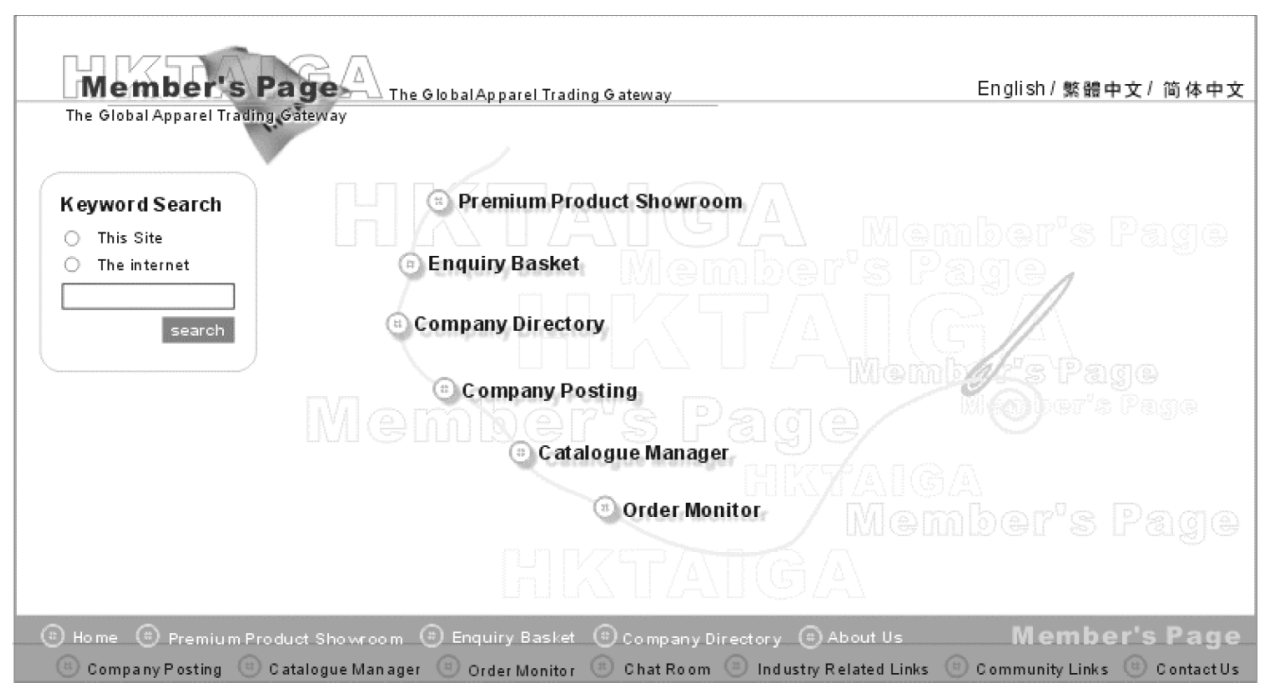

Figure 4. The EC front-end Web page of HKTAIGA.

combination of an image search engine, categorized product trees, and an intranet keyword search mechanism (such as Ultraseek). The tracking functions record usage patterns to identify the Web pages that are of major concern to individuals or groups. Apart from responding to users' requests, news, advertisements, and other information are forwarded directly to them according to their preferences by using push technology [34]. Another module underway integrates the infrastructure; EC front-end and workflow systems establish vertical and horizontals portals as mentioned above [35]. Established for secured e-commerce platforms, www.ApparelCircle.com supports major portals in conjunction with the service providers, such as Cable \& Wireless Hongkong Telecom IMS Limited and UNI-Tech Technologies Limited. The EC front-end system was handed over to the non-profit organizations, Hong Kong Productivity Council (HKPC) and Quick Response Center (QRC), for support of operations, service, and management. 


\subsection{Summary of EC Impact}

In an EC-based supply chain, the product development time may be reduced from six weeks to two. The buyer inventory in replenishment can be reduced from 17 weeks to an average 6 to 8 weeks and the total cycle time for orders can be cut from 40 to 20 weeks (see Figure 5). The supply channels are transformed from a hierarchical structure to a star-based direct link as shown in Figure 6. The manufacturers are organized either by product provided (such as button and lace) or general company characteristics. The former provided a full coordination on the shortened supply chain and the latter resulted in better procurement consolidation.

With HKTAIGA as the justification of our impact study in Section 3, we can see that from Table 4, HKTAIGA started its implementation from the first to the third phase, whereas the fourth phase is still in the planning stage. The first phase required ten workers to build a CD-ROM media to catalog its product information, which facilitates the storage and retrieval of such information. It involved 20 pilot companies with an investment of $\$ 1.01$ million for nearly 2 years. The problem that occurred in this phase was the delay in the distribution of CDs to the buyers, which affected the communication between buyers and sellers. Therefore in the second phase, as the number of buyers and suppliers increased, HKTAIGA decided to build up a communication infrastructure to solve this problem and to enhance the information transfer/exchange between buyers and sellers. This system required buyers to become connected to the suppliers' server in order to communicate with them, thus in the third phase HKTAIGA targeted migration of its communication channel onto the EC front-end while expanding it globally. In this phase suppliers can catalog their product information in a Web site allowing buyers to view their information without any geographical restriction. Not only for the use of information exchange, the fourth phase is planned to extend the EC front-end infrastructure into a portal with transaction and logistic functions.

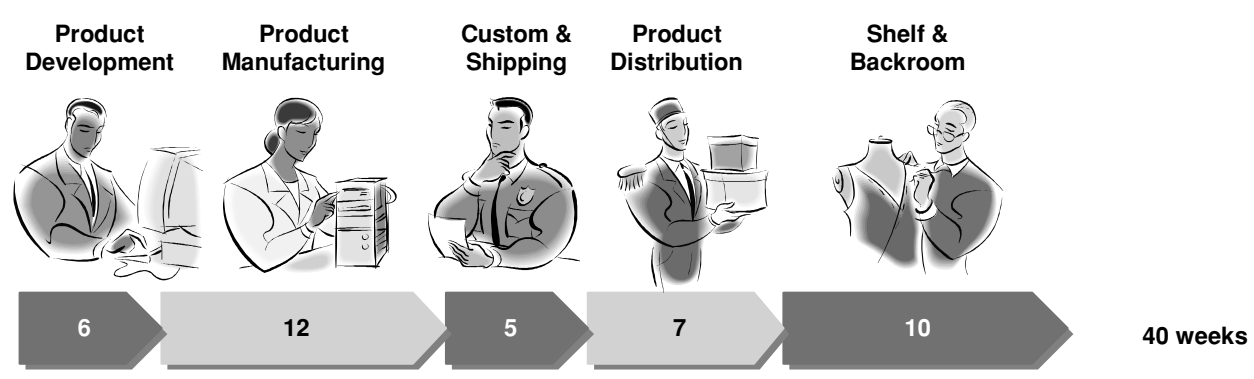

(a) Traditional textile supply chain
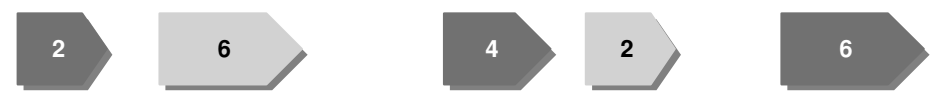

20 weeks

(a) EC-based textile supply chain

Figure 5. Cycle time of textile supply chain. 


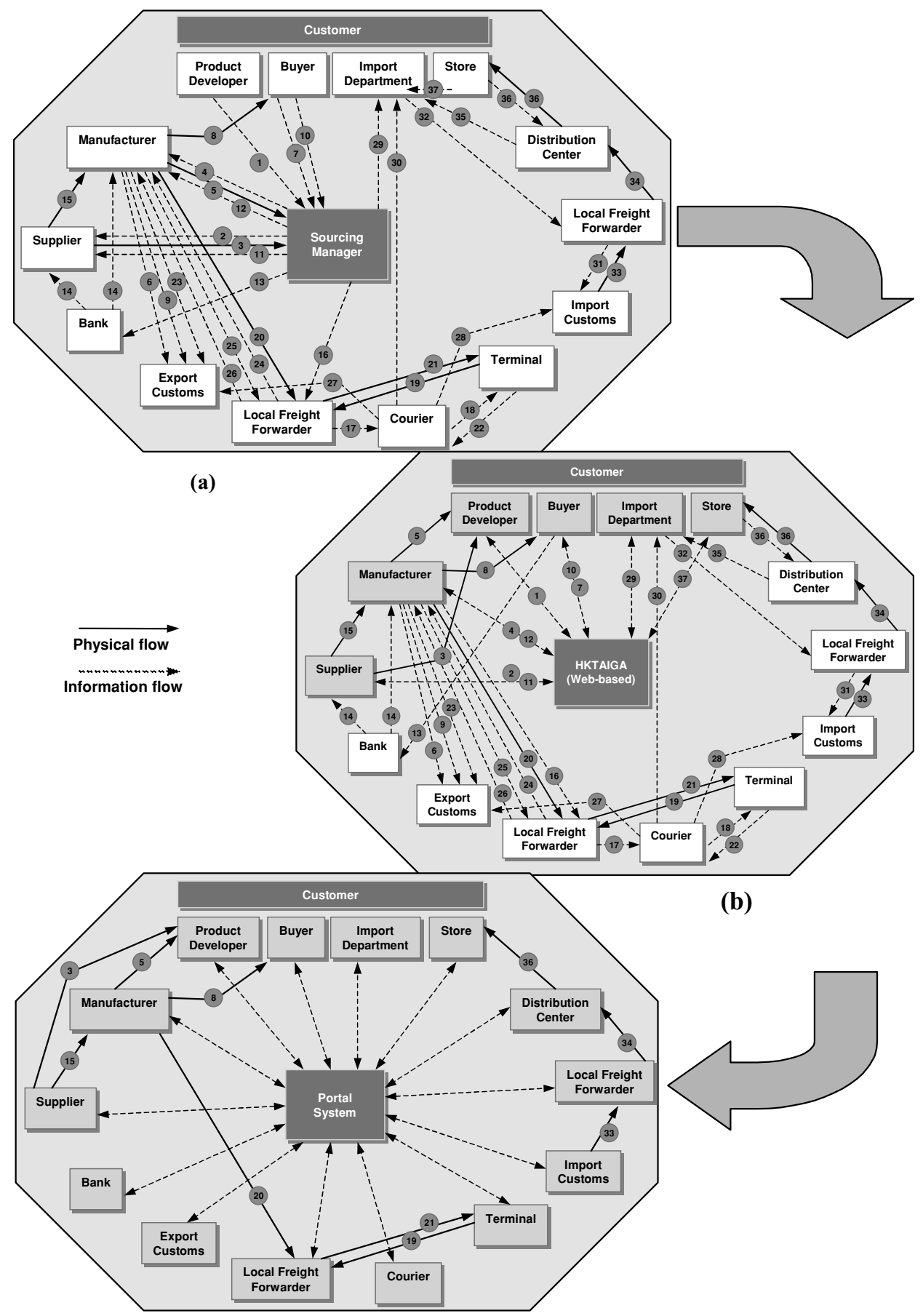

(c)

Figure 6. (a) Traditional, (b) EC-based, and (c) portal systems in textile supply chain. 
With the EC front-end system, HKTAIGA mainly provides the communication infrastructure that serves partial system requirement for sellers. Since it first launched on the Internet, it has accumulated a total of 1,206 members, in which $60.5 \%$ and $39.5 \%$ are sellers (write users) and buyers (read users), respectively. Both the read and write users require Internet accesses from Internet service providers (ISPs) to access and manage their database and EC functions via HKTAIGA and the EC front-end system. The Quick Response Center (QRC), a semigovernment organization, has been organizing workshops, seminars, and conferences to provide training on installation and management. With the electronic catalogs, buyers can use hybrid searching mechanisms (text/image, product/company, and Intranet/extranet) to efficiently search for information online. In addition, the sellers use the push technology to inform the target buyers of the new product information. The discussion group and online talk functions are responsible for the availability of the quotation/negotiation communication channel.

The EC impact that HKTAIGA brought to both buyers and sellers is shown in Table 5. In the traditional trade, suppliers have to produce paper catalogs for buyers to source the material information, but with HKTAIGA buyers can browse through suppliers' online catalogs. Similarly, with quotation and negotiation, instead of face-to-face contacts in the traditional trade, buyers and sellers can utilize the EC media offered by HKTIAGA to exchange information in a timely and transparent fashion. In addition to the traditional payment by cash, check, or credit card, some of HKTAIGA members also provide access to company-to-company proprietary or third-party online transaction functions. The delivery service is enhanced by Web-based tracking and tracing functions by third-party logistics companies in alliance.

Table 6 illustrates the amount of cost reduction gained by five material suppliers and two buyers after adopting HKTAIGA. An example of the material supplier is Loko Lace, an accessories supplier that mainly wants to use HKTAIGA for marketing purposes. Loko Lace believes that putting their contact details and description of their company on www.HKTAIGA.com is another way to advertise their company to potential buyers in the textile industry. The cost reduction within each business operation is estimated in percentage. The majority material suppliers had $0-10 \%$ of cost reduction in product catalog production, physical visit and presentation to clients, enquiries followup, and storage space. An example of the buyer is Bossini Enterprises Ltd., a well-known retail clothes chain store in Hong Kong that mainly applies the product search facility in www.HKTAIGA.com. It was seen that $60 \%$ of the buyers have $11-50 \%$ of cost reduction in material sourcing and storage space and $80 \%$ of them have $0-10 \%$ cost reduction in physical visits to suppliers.

\subsection{Guidelines from HKTAIGA}

With HKTAIGA as a case study to illustrate the impact of migrating procurement business process onto the Internet, we have learned that in order to maximize the benefits and minimize risk or loss, careful planning is essential before 
Table 5

\begin{tabular}{|c|c|c|c|c|}
\hline & \multicolumn{4}{|c|}{ Categories of Impact } \\
\hline & \multicolumn{2}{|r|}{ Buyer } & \multicolumn{2}{|c|}{ Seller } \\
\hline & Traditional & $E C$ & Traditional & $E C$ \\
\hline \multicolumn{5}{|l|}{ Business process } \\
\hline Pre-sourcing & $\begin{array}{l}\text { Sample books and catalogs } \\
\text { search or showroom visit }\end{array}$ & $\begin{array}{l}\text { Online electronic catalogs or } \\
\text { product search, product } \\
\text { comparison in hktaiga.com }\end{array}$ & $\begin{array}{l}\text { Production of printed catalogs } \\
\text { by out-contracting to } \\
\text { production house/printer, } \\
\text { and hand-made sample } \\
\text { cards/books/hangers }\end{array}$ & $\begin{array}{l}\text { Creation and update of online } \\
\text { electronic catalogs with } \\
\text { hktaiga.com cataloging }\end{array}$ \\
\hline \multicolumn{5}{|l|}{ Procurement } \\
\hline Quotation & $\begin{array}{l}\text { Physical meetings with } \\
\text { buyers and/or post/ } \\
\text { telephone/fax contacts }\end{array}$ & $\begin{array}{l}\text { Electronic and automated } \\
\text { inquiry in sample request forms }\end{array}$ & $\begin{array}{l}\text { Manual preparation of quotation } \\
\text { by computers, and/or } \\
\text { handwriting and typing }\end{array}$ & $\begin{array}{l}\text { Electronic, quick, and customizable } \\
\text { quotations directly to buyers } \\
\text { by online communication }\end{array}$ \\
\hline Negotiation & $\begin{array}{l}\text { Physical meeting with } \\
\text { sellers and/or } \\
\text { telephone/fax contacts }\end{array}$ & $\begin{array}{l}\text { Transparent and timely request } \\
\text { directly to sellers via hktaiga.com } \\
\text { with Message, Discussion Board, } \\
\text { and Company Homepage contact } \\
\text { with online communication }\end{array}$ & $\begin{array}{l}\text { Physical meeting with buyers } \\
\text { and/or telephone/fax contacts }\end{array}$ & $\begin{array}{l}\text { Transparent, timely, and customizable } \\
\text { response directly to buyers } \\
\text { with Message, Discussion Board } \\
\text { with online communication }\end{array}$ \\
\hline $\begin{array}{l}\text { Order } \\
\text { placement }\end{array}$ & $\begin{array}{l}\text { Manual preparation of } \\
\text { purchasing orders (POs), i.e., } \\
\text { handwritten \& typed POs; } \\
\text { delivery of PO copies via fax } \\
\text { and PO original copies by } \\
\text { mail/courier to seller }\end{array}$ & $\begin{array}{l}\text { Automated, synthesized, and modifiable } \\
\text { placement through shopping } \\
\text { cart via hktaiga.com }\end{array}$ & $\begin{array}{l}\text { Manual preparation of sales } \\
\text { contract (hand-typed/written) } \\
\text { upon receiving of; delivery of } \\
\text { sales contract copies via fax and } \\
\text { sales contract original copies } \\
\text { by mail/courier to buyer }\end{array}$ & $\begin{array}{l}\text { Automated consolidation and } \\
\text { efficient and error-free POs via } \\
\text { hktaiga.com }\end{array}$ \\
\hline Transaction & By cash/check/credit card & $\begin{array}{l}\text { By cash/check/credit card; } \\
\text { company-to-company electronic } \\
\text { payment }\end{array}$ & $\begin{array}{l}\text { Payment made via } \\
\text { cash/check/credit card }\end{array}$ & $\begin{array}{l}\text { Payment made via cash/check/ } \\
\text { credit card or proprietary/ } \\
\text { third-party online payment } \\
\text { mechanism. }\end{array}$ \\
\hline Post-delivery & By mail/courier & $\begin{array}{l}\text { By mail/courier with online } \\
\text { tracking/tracing functions }\end{array}$ & $\begin{array}{l}\text { Choices of delivery methods } \\
\text { are given to buyers }\end{array}$ & $\begin{array}{l}\text { Choices of delivery methods are } \\
\text { given to buyers or third-party } \\
\text { logistics in alliance }\end{array}$ \\
\hline
\end{tabular}


Table 6

The Cost Reduction of Companies by Adopting HKTAIGA

\begin{tabular}{|c|c|c|c|c|}
\hline \multicolumn{5}{|c|}{ Material Suppliers } \\
\hline \multirow[b]{2}{*}{ Business Operation } & \multicolumn{4}{|c|}{ Reduction of cost by percentage } \\
\hline & $0-10 \%$ & $11-50 \%$ & Over $50 \%$ & $\mathrm{~N} / \mathrm{A}$ \\
\hline Product catalog production & $50 \%$ & $16.6 \%$ & $16.6 \%$ & $16.6 \%$ \\
\hline Physical visit \& presentation to clients & $50 \%$ & $16.6 \%$ & $16.6 \%$ & $16.6 \%$ \\
\hline Order \& request follow up & $50 \%$ & $16.6 \%$ & - & $33.4 \%$ \\
\hline \multirow[t]{2}{*}{ Storage space } & $50 \%$ & $16.6 \%$ & $16.6 \%$ & $16.6 \%$ \\
\hline & Buyers & & & \\
\hline Material sourcing & $40 \%$ & $60 \%$ & - & - \\
\hline Physical visit to suppliers & $80 \%$ & $20 \%$ & - & - \\
\hline Storage space & $40 \%$ & $60 \%$ & - & - \\
\hline
\end{tabular}

the migration. HKTAIGA has followed the four-phase migration model starting with the digitization of information to moving onto an EC front-end. Nevertheless, each phase has to be accompanied by the right technical, security, and financial requirements in order for each phase to occur and proceed onto the next phase successfully. Some problems are expected to arise in each phase and will be treated as input for the next phase. For instance, in the first phase there was a communication delay between buyers and suppliers with the CD-ROM media, therefore in the second phase, they decided to build a communication infrastructure to solve the problem. The impact brought by HKTAIGA included handling processes electronically in a paperless environment which saves time and costs, enhancing communication and information exchange between each entity (e.g., buyers and suppliers), and operating in a more efficient and errorfree way within the procurement process.

\section{CONCLUSIONS}

IT has been adopted to enhance the global competitiveness of various industries through the widespread application of cost-effective EC. Many Internet-based systems have been designed and developed for various industrial applications and they mainly center on information communication infrastructure, coordination in production and distribution, and purchasing functions with security mechanisms. In this article, we propose a model of impact study of EC on procurement in SCM accompanied by a four-phase migration model and impact categorization table. An example of EC procurement within the textile industry is also presented to demonstrate impact on buyers, sellers, and procurement processes. Nevertheless the procurement migration process is determined by the size of company and nature of the industry, and the requirements involved may vary as well. Although this study cannot totally reflect the EC deployment feasibility, this article provides guidelines to conduct an impact analysis in the procurement process. The following gives a list of future directions: 
- Extend this study to include all the processes (such as transactions and shipment) in general supply chains to gain the insight for overall performance analysis.

- Investigate the characteristics (such as frequency and types) of information flow in supply chains to develop an economy model of information distribution and coordination.

- Compare the traditional and EC-based procurement processes on the issues of information and service quality.

\section{REFERENCES}

[1] J. C. Westland and T. H. K. Clark, Global Electronic Commerce: Theory and Case Study. Cambridge, MA: MIT Press, 1990.

[2] R. Kalakota and A. B. Whinston, Frontiers of Electronic Commerce. Addison-Wesley, Reading, MA: 1996.

[3] E. Christiaanse and R.-J. Zimmerman, "Managing electronic channels: The KLM Cargo Cyberpets case," Journal of Information Technology, vol. 14, no. 2, pp. 123-135, 1999.

[4] R. Alt, K. M. Grünauer, and C. Reichmayr, "Interaction of electronic commerce and supply chain management-Insights from 'The Swatch Group'," in Proc. of the 33rd Hawaii International Conference on System Science, 2000.

[5] M. M. Srinivasan, J. M. Reeve, and M. P. Singh, "E-Business in the supply chain," in Proc. of International Conference on Advances in Infrastructure for Electronic Business Science, and Education on the Internet, SSGRR, Italy, 2000.

[6] C. Loebbecke, P. Powell, and C. Gallagher, "Buy the book: Electronic commerce in the book trade," Journal of Information Technology, vol. 14, no. 3, pp. 295-301, 1999.

[7] T. Matsuda, "An invisible barrier to implement electronic market systems: A case study of the Japanese produce market," in Proc. of International Conference on Advances in Infrastructure for Electronic Business Science, and Education on the Internet, Italy, abstract from CD-ROM, 2000.

[8] N. M. Sadeh, D. W. Hildum, and D. Kjenstad, "Intelligent e-supply chain decision support," in Proc. of International Conference on Electronic Commerce, Seoul, 2000.

[9] O. Koppius, "Dimensions of intangible goods," Proc. of the 32nd Hawaii International Conference on System Science, CD-ROM, 1999.

[10] K. Eyholzer and D. Hunziker, "The use of the internet in procurement: An empirical analysis," in Proc. of the 8th European Conference on Information Systems, H. R. Hansen et al., Vienna, 2000, pp. 335-342.

[11] A. Fisher, "It's a small world after all," Financial Times, pp. 6-7, Winter, 2000a.

[12] S. Avery, "E-procurement: A wealth of information for buyers," Purchasing, Sept. 21, 2000a.

[13] A. Fisher, "Playing catch up," Financial Times, pp. 22-23, Winter, 2000b.

[14] S. Avery, "E-procurement is one tool to reduce costs, cycle time," Purchasing, Sept. 21, $2000 \mathrm{~b}$.

[15] W. Atkinson, "Railway's shift to strategic sourcing and SCM paves pathway for e-procurement," Purchasing, Sept. 21, 2000.

[16] W. Atkinson, "Print firm uses e-buying to strengthen its supply chain," Purchasing, Sept. 21, 2000.

[17] W. Atkinson, "E-procurement is a natural for MRO purchasing," Purchasing, Sept. 21, 2000.

[18] R. Kasturi, "Mission-critical e-procurement," Intelligent Enterprise, Sept. 8, 2000.

[19] N. Timmins, "Public spending," Financial Times, p. 9, Winter, 2000.

[20] S. Croom, "The impact of Web-based procurement on the management of operating resource supply," The Journal of Supply Chain Management, Winter, vol. 36, no. 1, issue 5, Winter, 2000.

[21] J. Gebauer, C. Beam, and A. Segev, "Impact of the Internet on procurement," Acquisition Review Quarterly, vol. 14, pp. 167-181, 1998.

[22] E. Rhodes and R. Carter, "Electronic commerce technologies and changing product distribution," International Journal of Technology Management, vol. 15, no. 1, issue 2, 1998.

[23] J. Carbone, "There's lots more to the Web than click and buy," Purchasing, vol. 127, issue 6, pp. S76-S77, 1999. 
[24] H. Philips, "E-commerce shortens the supply chain," New Zealand Manufacturer, pp. 12-13, Sept.-Oct. 1999.

[25] S. Hill, "Supply chain management in the age of e-commerce," Apparel Industry Magazine, pp. 60-63, March 1999.

[26] R. Clarke, Introduction to Electronic Payment Mechanisms, Available HTTP: http://www.anu. edu.au/people/Roger.Clarke/EC/EPMIntro.html, 1998.

[27] R. Clarke, "Financial EDI in Australia," 1996, Available HTTP: http:/ / www.anu.edu.au/people/ Roger.Clarke/EC/FEDIPreface.html.

[28] Mb Digital Marketing, "Summary of electronic payment systems (EPSs), 1996, Available HTTP: http://www.backe.com/epssum.html.

[29] Mondex International Ltd., Mondex electronic cash, 2000, Available HTTP: http:/ /195.157.97. 145:8016/.

[30] Collins, Philippa, "E-logistics 2000: Re-thinking the supply chain." Management Services, pp. 6-10, June 2000.

[31] S. Henderson, R. Illidge, and P. Mchardy, Management for Engineers. Oxford, England: Butterworth Heinemann, 1994.

[32] Hong Kong Government Industry Department, 1995 Techno-Economic and Market Research Study on Hong Kong's Textiles and Clothing Industries, Volume II: Hong Kong's Softgoods Industry in the Global Supply Chain, prepared by Kurt Salmon Associates, 1996.

[33] B. P.-C Yen and C. J. Su, "Information technology infrastructure for textile and apparel industry in Hong Kong," International Journal of Electronic Markets, vol. 7, no. 2, pp. 9-12.4, 1997.

[34] B. P.-C. Yen, "Electronic commerce front-end in apparel supply chain," International Journal of Computers E Industrial Engineering, vol. 42, pp. 471-480, 2002.

[35] B. P.-C. Yen and E. O. S. Ng, "Migrating procurement onto the Internet," Electronic Commerce Research Journal, vol. 2, no. 1-2, pp. 113-134, 2002. 